\title{
Socioeconomic Impacts of Myanmar's Malay Muslim Immigrant in Malaysia
}

\author{
Amran Awang ${ }^{1}$, Ahmad Ismail $^{1} \&$ Zulkafli Mansor ${ }^{1}$ \\ ${ }^{1}$ Faculty of Business and Management, University of Technology MARA (UTM), Perlis Campus, Arau Perlis, \\ Malaysia
}

Correspondence: Amran Awang, Faculty of Business and Management, University of Technology MARA (UTM), Perlis Campus, 02600 Arau Perlis, Malaysia. E-mail: amranawang@yahoo.com

Received: November 27, 2013

Accepted: December 24, 2013 Online Published: January 26, 2014

doi:10.5539/ass.v10n4p161

URL: http://dx.doi.org/10.5539/ass.v10n4p161

\begin{abstract}
The study examines the socioeconomic impact of Myanmar's Malay Muslim immigrant (MMMI) in Langkawi on the issues of socioeconomic and environmental perspectives. The study investigates the extent of impact due to the presence of immigrants in wage competitiveness in the local jobs, distraction of small sea fishing activities and the impact of the environment of the immigrant's dwelling area. The study establishes indicator on the national's economic vision towards innovation and automation of the construction and plantation industry advances. The aim of the research is to study what is the perception of the community towards the existence of the MMMI. The study uses multiple regression analysis to support the proposed hypothesis. The findings ascertained to some extent regarding issues in wage competitiveness. The immigrants were found to contribute to environmental nuisance to the surrounding area. Consequently, the analysis justified respondents had showed agreement on the issue that the immigrants are threatening local community's well beings.
\end{abstract}

Keywords: immigrants, socioeconomic, wage competitiveness, environmental nuisance, career distraction, labor economics theory, Malaysia

\section{Introduction}

Since the immigrant issue becomes an international issue currently, there are many factors such as economy, politics, and social that contributed to the issue of immigration. The most obvious reason in the global migration is then pushed and pulled factors. Among others, the pushed factors contribute to inadequate jobs for local citizen in the home country, fewer opportunities, primitive condition of standard of living, political concerns, poor medical care, unable to practice religion, reduction of wealth, natural disasters prone, death threats, slavery, pollution, inadequate housing, powerful landlords, bullying, and poor chances of finding courtship. On the other hand, among the pulled variables factor are better job opportunity in the host country, better living conditions, political and/or religious freedom, better enjoyment, better education, better medical care, better security, family links, and better chance of finding courtship. In Malaysia, most of the immigrants enter the country due to economic reasons and they are here to be employed as foreign workers. The attractions why they are coming to Malaysia was due to significant wage differential and abundant job opportunities compared to their motherland.

This research focuses on a small group of immigrants coming from Myanmar and landed in Langkawi specifically in Bukit Malut area (refer Appendix A). The study examines the impact of the economy, social and environmental perspectives after the immigrants settled down in the area. This area appears to be a lasting settlement for these immigrants. These immigrants are Malay descendent and communicate in Malay language with the northern dialect and embraced Islam. Variables of the study are the wage competitiveness in the local construction activities, disruption of small sea fishing local activities and the environment of the immigrant's dwelling area. The purpose of the research is to examine the level of perception among the local community towards those socioeconomic impacts due to the existence of the MMMI.

Myanmar Muslim is a descendent of Malay, Arab, Rohingya, and as such comprising of 5 percent of the total population of Myanmar (Nordin, 2009). The total population of Myanmar in 2005 is about 50 million people. Since 1980s about 250,000 Myanmar's become refugees, they are the Rohingya people staying on the border of Myanmar and Bangladesh. Concurrently, the majority of the other Muslim is staying in the southern part of Myanmar along the border of Myanmar-Thailand. Most of them are Malay Muslims live in this region and their 
main economic activities capitalized in small time fishing.

Ten years later in 1988, when the pro-democracy movement in Myanmar was suppressed by the military government, a significant number of Burmese left the capital to border areas opposite to Thailand and stayed among the ethnic minority population. Lack of freedom and human rights violations seem to be the major force that drove people from Myanmar (Chantavanich, 2007). Nonetheless, the influx of immigrants continued because of the economic staleness in Myanmar.

The earliest arrival of the Myanmar's Malay Muslim immigrants to Langkawi sometime in the late 1970s, roughly 100 of them entered mainly female and children. There were no male adults with them during that time. They were allocated at the government multi-purpose hall in Padang Lalang, Langkawi. Later on they were transferred to the mainland of Malaysia peninsular but the local natives were unaware of the exact location. Ten years later in 1988 a large group of MMMI arrived in Langkawi, and they were placed at Bukit Malut, Langkawi as their temporary home. These immigrants keep on coming and it was estimated about 2000 people in 1990s and now the estimated figure rises to nearly 6000 people. Generally immigrants clustered in a small number of geographic areas (Borjas, 2006). Presently, the Myanmar's children are attending school in the public school nearby their settlement. In reality, our Government failed to furnish proper housing needs of these immigrants, and therefore they end up building and living in squatter settlements, the situation then encourages immigrants' ethnic and community concentration (Castles, 2000).

The geographical proximity between southern Myanmar and northern Malaysia enable easy entry and exit access into both countries. In addition, they have family ties with other immigrants who have entered Langkawi earlier. They find the entry even easier with these family members providing shelter and protection in their first entry.

Initially Langkawi local community seems understanding and tolerable on the needs of illegal immigrant from Myanmar due to similarity in religious believe, language spoken, and majority of the natives strongly supporting UMNO, the political party on common political agenda. Furthermore, Langkawi local community ignored the issue as long as no threat to their livelihood. However, Malaysian immigration officials prefer to admit illegal Indonesians or Muslim Filipinos immigrants compared to non-Muslim Filipinos or Burmese, merely due to ethnic and religious similarities (Castles, 2000).

Since the mass arrival of the MMMI in late 1980s, mild criminal activities like stealing of the fishing nets, boats' engines, small boats and the fishing equipments belong to the local fishermen are increasing. Myanmar's main job is working as small time fisherman and employed as unskilled workers. Some reports were made by the locals on the losses incurred by them to the local police but there were no action taken by the authority. There were occasions where these male immigrants were fighting with the natives, but when it becomes the police case, the local natives were blamed on the ground that these immigrants were protected by the higher authority and it seems that they were given the immunity of the law. Kanapathy (2006) cited that when foreign workers are growing larger, the situation could harm the local security where crime rates are going to be alarming and in the incidence of diseases it could become contagious.

The study bears out some theories related to the immigrant studies such as the socioeconomic and labor economic school of thoughts. Primarily, the principal cause of the human migration is due to the economic reasons and as a result social well beings of the host country are at stake. The aim of the research is to analyze what is the perception of the community towards the existence of the MMMI on the issue of economic, social, and local environment.

\section{Present Scenario}

Malaysia has relied on the regional labor market for low to medium skilled workers since the early 1970s to fuel growth and facilitate structural adjustment without a hollowing-out effect on the economy as cited in Kanapathy (2006). He iterated further that the orientation of national policies since 2002 from short term counter cyclical measures to more medium and long term measures to address structural rigidities has contributed to a stronger and healthier economy that is able to weather external shock. The economic prosperity had boosted demand for workers in many economic sectors and in addition the decreasing international comparative advantage in labor intensive products required the business to apply cost cutting (Chantavanich, 2007).

In Malaysia there are a substantial number of immigrants coming from poorer neighboring country like Indonesia. However, there are sizeable numbers of immigrants hailing from the Philippines, Thailand, the Han Chinese, Vietnam, Bangladesh, Nepal, India or South Asian descent. The NGOs have estimated that in Sabah only there are about 2 million immigrants comprising of two third of the state's population (Quek \& Kim, 2006). This pattern might be too optimistic, but most of the immigrants were from Indonesia and Philippines. 
The number of immigrants at that particular time comprised a substantial portion and worrisome the host country's population. To boot, its complex ethnic balance is a result of our previous colonial's policy of labor import for the tin mine and rubber plantation imperatives (Castles, 2000).

Immigrant who have high levels of productivity and who adapt rapidly to condition in the host's country labor market can make a substantial contribution to economic growth (Borjas, 2006). Inversely, Borjas (2006) further elaborated that a nation secures economic benefits of immigration, but the trade-offs are immigration tend to decrease the size of the economic pie available to local natives.

Malaysian politics are shaped by the country's geography, racial, religious and ethnic diversity (MYREN, 2006). Malaysia is a unique country with a history of traditional diversification based on the ethnic groups' differentials. Generally, national policy encourages controlled migration for the purpose of trade, work, religious and social contact. Alternatively, the situation attracts migration from neighboring countries due to the differences in per-capita income (Borjas, 2006). Since 1980s, Malaysian progressive economic management has led to a rapid economic growth and industrialization that turns Malaysia into a 'second-wave tiger economy', but labor shortages in many sectors getting more critical (Castles, 2000). Moreover, a report also evidenced that Malaysia became a haven for migrating due to brain drain syndrome when quite a number of its citizens migrated for work and residing abroad (Kassim, 2005).

The government of Malaysia maintained the acceptance of immigrants based on humanitarian and refugee grounds especially for Muslim immigrant from Indochina after the conclusion of the Vietnam War in 1975 as well as refugee from Myanmar on the humanitarian and religious ground in the 1970s and 1980s. Both asylum seekers and refugees are still deemed illegal immigrants in Malaysia (MYREN, 2006).

Malaysia dependency on foreign workers has been evidently critical in the last 15 years, there were only 4 percent of immigrant workers in 1990, but now the number has increased to 12 percent as compared to the total Malaysian workforce in 2005 (Kassim, 2005). However, in short-run, immigrants will help boost the supply of labor according to skill groups in the country. Moreover, the situation creates intense competition for jobs and consequently lowers the salary structure for the similarly-skilled in the job market (Aydemir, 2007).

Malaysian economic growth remains intact and the physical development successfully executed according to plan. This is due to the mobility of immigrant labor in response to regional differences in economic opportunities that improved labor market efficiency significantly, in other words, immigrants act as grease on the wheels of the labor market (Borjas, 2001).

Many reports claim that immigrant and native workers are not perfect substitutes within narrowly defined skill groups but we cannot rule out the hypothesis that comparably skilled immigrant and native workers are perfect substitutes based on factor price and supplies (Borjas et al., 2008). However, in normal circumstances immigrant is the best reliever in the labor market in the developing countries based on the availability of supply. Aydemir (2007) noted that migration induces shifting up of the supply of labor and associated with a movement of wages in the opposite direction.

\section{Immigrant Workers' Social and Economic Impact}

Presence of immigrant workers into a country does not necessarily lead to betterment for a country in all aspects. Experiences from other countries help clarify the social and economic impacts of a nation due to the presence of immigrants. The effects of assimilation, currency outflow, settlement, culture and political are then discussed.

The process of assimilation makes immigrants more substitutable to native and may lead to increase in wage competition (Orrenius \& Zavodny, 2006). The process of assimilation may come in the form of marriage to the native especially immigrant from Indonesia and Southern Philippine where their physical, cultural and linguistic processes are almost alike. There are cases where the Christian female immigrants from Philippine converted to Islam just to fix the permanent resident status of Malaysia. The phenomenon was observed in the state of Sabah as reported in Sidiq (2005).

Employment of the immigrants leads to a loss in revenue through their remittances, delays automation and mechanization, suppresses local pay, imposes a heavy toll on social amenities and social services, reintroduction diseases once under controlled in Malaysia, a threat to security (Kassim, 2006). In 2008, Malaysia lost in revenue to a total of RM17 billions when foreign workers from all sectors of economy remits money to their respective home countries (Selamat, 2008). This scenario has been common in numbers of countries in the world when restrictive tone was over ruled allowing free flow of capital across national borders (Caselli \& Feyrer, 2007; Giannone \& Lenza, 2009).

Another issue related to the phenomena also bears on illegal immigration and unplanned physical settlement for 
the incumbents. Sloppiness in erecting and maintaining such facilities lead to endless congestions and the potential for social tension is inevitable (Castles, 2000). Now Malaysia is becoming to be a transit spot for immigrant workers prior to their departure for other countries (Selamat, 2009). Malaysia is like many other developing countries which is a multiethnic developing nation, citizenship is not well institutionalized and due to that the arrival and incorporation of illegal immigrants from neighboring countries is possible through a kind of fake documentation scams or real documentation falsely obtained (Sidiq, 2005). The evidences beings were when governments failed to trace the presence of the immigrants and the existence of unplanned settlement and the community formation among immigrants are getting intensified (Castles, 2000).

A fear with the continued influx of immigrants who communicate similar language, practice common cultural and religious affinities with local Bumiputera could be detrimental to a country's political system. The political parties may take advantage of the situations, thus unethical practices of political parties by using the immigrants could upset the delicate political and economic power-sharing largely based on ethnicity (Kassim, 1991). The Chinese political groups feared that Indonesian immigration would alter the ethnic balance to their disadvantage, while the government party, UMNO and Islamic opposition party PAS, both supported Indonesian entries as a potential boost to Malay and Islamic interest it becoming a common practice to give illegal workers permanent resident cards during election to increase the Malay votes (Castles, 2000).

The anger and frustration expressed by the natives is consistent with the finding by Borjas (2006). The immigrants flow consists mainly of low-skill workers will exacerbate the economic problems of native low skill workers and will likely create severe cultural and social dislocation (Borjas, 2006). Conversely, the employers feel grateful because they could bring down the cost of construction or operations with the usage of the immigrant workers. A key insight of economic theory is that immigration has distributional impacts, reducing the income of workers who compete with immigrants and raising the income of those who employ immigrants or purchase immigrant-provided services (Borjas, 2006).

The immigrants with lack of skills that employers demand and find it difficult to adapt, immigration may increase the size of the population that requires public assistance and exacerbate ethnic and racial inequality (Borjas, 2006). This finding is relevant to the Myanmar's Malay immigrants in Langkawi whereby they are neglecting the courtesy and norms, not educated, low skills workers and most of their children are allowed to be schooled locally in the government sponsored school exacerbate the uneasy feeling among the local community.

It was understood that in 1990s the authority had issued 2000 Malaysian identity cards (Mykad) to Myanmar's immigrants but the numbers could be unofficial. Those who possess Mykad are considered as Malays and Bumiputeras and enjoy privileges such as alienation of government land, voting right, a discount on real estate purchase and as such. Some of them have been granted with a better housing facility within the island depriving the rights of the local community.

The literature survey furnishes a wide gap in socioeconomic outcomes of a country. Issues in wage competitiveness, distraction to community well beings and threat to physical environment prove inevitable. Figure 1 suggests the research model of the study.

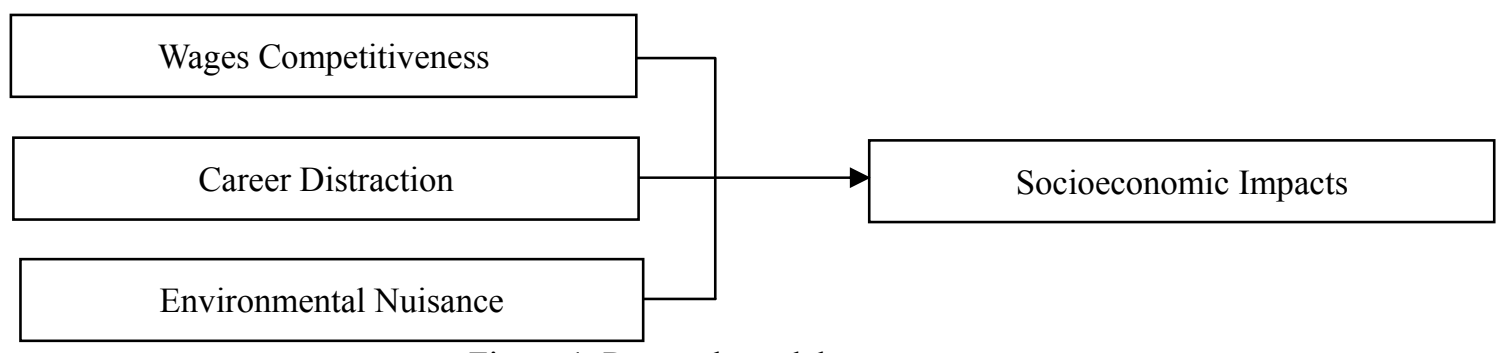

Figure 1. Research model

Hence, we posit:

$H_{1}$ : Wage competitiveness explains higher perceived socioeconomic impacts

$\mathrm{H}_{2}$ : Career distraction explains higher perceived socioeconomic impacts

$H_{3}$ : Environmental nuisance explains higher perceived socioeconomic impacts. 


\section{Methodology}

\subsection{Research Design}

The research capitalizes on survey method where almost all adult local communities where the respondents of the study. The adult population living in Bukit Malut area is approximately 500. The survey was done on the cross sectional basis using questionnaires. The questionnaires were circulated to all respondents and they responded to the questions in the presence of the researchers to assist if they were unable to fill up the response. Two enumerators among the local community were employed to run the follow up and collect the questionnaire if the respondents fail to submit on the fixed date. Items used in the questionnaire listed in Table 1 in Appendix B.

The dependent variable (perception of natives along the socioeconomic impacts due to the presence of MMMI) operationalised on a 5-item 5-point Likert-scale. For the independent variables, wage competitiveness in local construction; distraction to small local fishermen fishing activities; and pollute the environment of the village area, similarly utilized 5-items 5-point Likert-scale format for level of agreement towards each item.

Data treatment runs through data cleansing and verification process. Verified data were entered into SPSS variable input page. Demographic data were analyzed to explain the distribution of the respondents' characteristics. For dependent and independent variables item analysis was done to ensure trends of responses. Each construct of IV and DV were analyzed for reliability scores to ensure their stability and consistency; therefore, the goodness of measures was justified. The variable then went through the formulation stage where prospective items combined into a composite scale representing a variable.

The hypotheses tested using MRA to ascertain model significance and beta coefficient significance. Level of acceptance was based on the significance level at $p<.05$ as suggested in the APA Publication Manual (2003). Limitation for the degree of confidence cited as a precaution to avoid the Type I error.

\subsection{Hypothesis Testing}

Since there is one dependent variable and three independent variables, therefore, the most appropriate analysis technique is the multiple regression analysis. Moreover, this research model is also expressed further in a mathematical model represented in the estimated regression equation as follows:

Socioeconomic impacts

$$
(Y)=a+b_{1} x_{1}+b_{2} x_{2}+b_{3} x_{3}+e
$$

Where;

Socioeconomic impacts

$$
(Y)=\text { Socioeconomic impacts of Myanmar's Malay Muslim Immigrant }
$$

$a=$ Constant (intercept)

$x_{1}=$ Wages competitiveness (WC)

$x_{2}=$ Career distraction $(\mathrm{CD})$

$x_{3}=$ Environmental nuisance $(\mathrm{EN})$

$e=$ error term

\section{Results}

The results were presented in two segments. First, the descriptive analysis comprised of the respondents demographic, item analysis and goodness of measures. Second, the inferential statistic that observed hypothesis tested using multiple regression analysis technique. The survey managed to secure about 24 percent represented by 120 respondents from the total population (estimated around 500 people) in the country of discipline. In social science research, securing more responses have been among the most debated issue in research methodology literature (Schoeni et al., 2013). However, we managed to get those responses through couple of enumerators employed among our students who were the local community. They revisited respondents who failed to submit the questionnaires in the first and second meetings.

\subsection{Descriptive Analysis}

Gender of the respondents was 80 percent male and they were represented by about equal age bracket distribution where 54 percent of the respondents were older who were more than 40 years old. Marital status showed 72 percent of the respondents were married and 90 percent of them were Muslim, however respondent 
who embrace Christian and Buddhist were also secured representing 10 percent of the respondents. Religious belief proved its consistencies with the race of the respondents that shared similar distribution.

\subsection{Item Analysis}

The frequency analysis performed on each item regarding wage competitiveness, career distraction and environmental nuisance proved lenient towards larger value on the scale. Ten percent or lesser of all observations tend to show disagreement on the scale.

\subsection{Goodness of Measures}

Reliability analysis was performed prior to composite score computation as suggested in Hair et al. (2006), the reliability alpha indicated all items were stable and internally consistent where wage competitiveness scored .89 , career distraction scored .86 and environmental nuisance .88 (Please refer Table 1). Thus the items fit to be figured into a variable, suggesting part of the goodness of measures verified.

Variables descriptive were performed to justify the placement of central tendency for each variable where the means, standard deviation and correlation coefficient of each variable as shown in Table 1.

Table 1. Mean, standard deviation and Cronbach's alpha

\begin{tabular}{llll}
\hline Variable & Mean & SD & Cronbach's alpha \\
\hline Socioeconomic impact & $\mathrm{NC}$ & $\mathrm{NC}$ & $\mathrm{NC}$ \\
Wages competitiveness & 3.2125 & .64854 & .887 \\
Career distraction & 3.0450 & .70512 & .860 \\
Environmental nuisance & 3.3751 & .6313 & .881 \\
\hline
\end{tabular}

$\mathrm{SD}=$ Standard deviation; $\mathrm{NC}=$ not computed.

\subsection{Inferential Statistics}

The inferential statistics were justified by the results of hypothesis testing. Multiple regression analysis was run to substantiate the relationship as suggested in the hypothesis. In ensuring the analysis was fit for the study, some assumptions regarding the representativeness were verified. Normality was verified using the normal distribution figure that is shown in the distribution of data resembled the bell shaped distribution in the produced histogram. Linearity was justified when the data lied about the regression curve. Heteroscedastic distribution was denied when the scatter plot showed the data distribution was well distributed and the plot verified as homoscedastic distribution as suggested in Hair et al. (2006).

\subsection{Hypothesis Testing}

Multiple regression analysis evaluates the natives' perceptions of socioeconomic impact towards Myanmar's Malay Muslim immigrants. Based on the result presented on the table 2, coefficient showed by $R^{2}$ is 0.723 and adjusted $R^{2}$ is 0.708 . This means that a 72.3 percent change in socioeconomic impact can be explained by overall Independent variables (IV) as a variable. Meanwhile, the other $27.7 \%$ of the changes in socioeconomic impacts could be explained by other factors, which are beyond the analysis. However, adjusted $R$ square showed 70.8 percent change in socioeconomic impacts was explained by multiple independent variables comprised of the competitive wages, career distraction and environmental nuisance that explained the criterion independently.

In table 2, the $t$-statistic for wage competitiveness $\left(x_{I}\right)$ is 3.021 , the number of observations in this research is 120 and the number of independent variables is 3 . Degree of freedom is equal to the number of observations minus the number of independent variables minus one as shown below: 
Table 2. Regression analysis

\begin{tabular}{lll}
\hline Variables & Unstandardized Beta & $t$-value \\
\hline Y-Intercept & $4.559^{* *}$ & 3.85 \\
& $(1.183)$ & \\
Wages Competitiveness & $0.532^{* *}$ & 3.021 \\
& $(0.176)$ & \\
Career Distraction & 0.112 & 0.849 \\
Environmental nuisance & $(0.132)$ & \\
R square & $0.362^{* *}$ & 3.143 \\
Adjusted R Square & $(0.115)$ & \\
\hline
\end{tabular}

${ }^{* *} p<.01 ; * p<.05$.

Number of observations $(n)=120$

Number of independent variable $(k)=3$

Degree of freedom $=n-k-1$

$$
\begin{aligned}
& =120-3-1 \\
& =116 .
\end{aligned}
$$

Since the degree of freedom is 116 , the critical $t$-value from the $t$-distribution table is 1.980 . Therefore, at a 95 percent confidence interval and at a significant level of 0.05 , the calculated $t$-value is more than $t$-distribution table $(3.021>1.980)$. Therefore there was a statistically significant relationship between wage competitiveness and socioeconomic impacts.

In the case of the independent variable of career distraction, the calculated $t$ - value is less than $t$ - distribution table $(0.849<1.980)$. Therefore the relationship between career distraction and socioeconomic impacts were not statistically significant.

The environmental nuisance impact of socioeconomic as on the calculated $t$ - value was more than $t-$ distribution table $(3.143>1.980)$. Therefore there was a statistically significant relationship between environmental nuisance and socioeconomic impact.

In addition, based on the regression unstandardized beta coefficient, wage competitiveness $(B=.532, p<0.004)$ significantly predicted local community's perception of socioeconomic impact. Career distraction $(B=.112$, $p>0.400)$ was not a significant predictor of socioeconomic impact. Whereas environmental nuisance $(\mathrm{B}=.362$, $\mathrm{p}<0.003$ ) was an important predictor of socioeconomic impacts.

Thus, from the above findings, we may derive the regression equation as follows:

Socioeconomic impacts

$$
(\mathrm{Y})=4.559+0.532 x_{1}+0.112 x_{2}(\mathrm{NS})+0.362 x_{3}+e
$$

$4.559=$ Intercept

$x_{l}=$ Wage Competitiveness

$x_{2}=$ Career distraction

$x_{3}=$ Environmental nuisance

\section{Discussion and Recommendation}

The results proved that the natives of Langkawi perceived some negative impacts that jeopardized their livelihood due to the settlement of the immigrants in Langkawi. The results prove that local community in Langkawi's negative perception towards the MMMI presence is substantive and justified. Harm to socioeconomic of the local community will be more detrimental and widespread if the MMMI remained and getting worse if they keep coming. Knowledge obtained from this study contributes to the socioeconomic body of knowledge. 
The results indicate wages competitiveness and environmental nuisance were statistically significant predictors of socioeconomic impacts. In other word, when the wage competitiveness and environmental nuisance are higher the impacts on socioeconomic in Langkawi also getting higher. In other word, every one unit change in wage competitiveness $\left(x_{1}\right)$, the socioeconomic impacts increase by .532. In the same vein, socioeconomic impacts change by .362 in every one unit change in environmental nuisance $\left(x_{3}\right)$. In the case of Y-intercept, the predicted value of wage competitiveness and environmental nuisance towards socioeconomic impacts begins at 4.559 points and higher on Y-axis. The findings were consistent with previous findings in the immigrant issues domestically and internationally. However, career distraction was not a significant predictor of socioeconomic impact; the study could not establish statistical significant beta coefficient that failed to reject the null hypothesis.

The current economic situation has led to questions over the value of wage competitiveness of the immigrants. Public opinion supports the view that immigrants affected natives' fishing career due to immigrants' willingness to accept lower wages. This is consistent with the law of demand and supply suggests that immigrants could cut wages by increasing the supply of workers (refer Figure 2 in Appendix C). The situation here explains the usual wage phenomenon inherent within developing economies as justified in labor economics studies (e.g. Kaufman, 2011). In addition, claim in Lindert and Williamson (2001) was than unsubstantiated whereby globalization will cause economic inequalities between recipient countries and the rest of the world as compared to report in Lewis $(1969,1983)$. These phenomena affecting especially developing countries such as Asia and Africa (Lewis, 1969, 1983), which had high labor intensity and low standard of living.

Political power and the authorities are called for in monitoring the situation in order to clear the negative perception of the local community towards the settlement of the MMMI. The authorities need to clear up the issue of the mass that MMMI settlement in Langkawi is significant as the urgency of the government. Inevitably, the number of immigrant keeps on increasing in no time and the situation is consistent with the immigrant theories such as the push-pull theory, migration movement due to prior relationships and immigrant theories of incorporation and assimilation. Sykes (2001) with respect to the USA's immigrant issues noted, "Some empirical research has been done, and the results tend to suggest that migration is frequently a source of gains in the world and in the country of immigration, though assuredly not always. Further, one cannot assume that the historical experience with immigration necessarily serves as an accurate predictor of the future, especially if immigration policies change. In particular, complete abolition of immigration restrictions would likely be inefficient for many countries, including the United States. The optimal immigration policy from the national perspective is more difficult to characterize, however, partly because the set of feasible alternatives is unclear, partly because the empirical issues are difficult and unresolved, and partly because the unabashed pursuit of national self interest likely collides with substantial moral objections."

The results empirically signify the polluted environment was due to immigrants' existence as an important effect that could jeopardize efforts in attracting domestic and foreign tourists to this resort island. Mohd. Tahir et al., (2010) study confirms the finding that environmental nuisance problems could be seen as the primary challenge and could enhance social problems. Thus, the public opinions signal strong sign of needs for the political power to enforce top down interventions to curb the problem.

\section{Concluding Remarks and Future Studies}

We can look at the significant and relevant of the migration through positive and negative perspectives. On one hand, immigrants contribute part and parcel of the host country's economic growth by offering the cheap labor alternative especially in the sector of labor intensive such as the plantation, construction, and industrial sector where local residence refuses to participate. On the other hand, immigrants especially the illegal immigrants bring along the problems to the host country such as crime, prostitution, drug trafficking, human trafficking, begging syndicate, critical diseases, and homesteaders.

Alonso (2011) in a UNDP's Committee of Development Policy (CDP) paper suggests that emigration affect both countries with costs, the country of origin bear the costs of breaking of family structures, destruction of emotional ties, loss of dynamic sectors of the population, waste of social capital and alike. On the other hand, for the recipient countries funding of policies for social integration of migrants, the effects deriving from greater ethnic and cultural heterogeneity, and as such. Moreover, Alonso (2011) noted, “...when emigration becomes a wide-spread and intensive phenomenon, it can feed a vicious circle which promotes a regressive dynamic of depopulation and the abandonment of productive activities in migrants' communities of origin. In these cases, young people plan their future in relation to the opportunities of migration, rather than seeking work and professional promotion in their own communities. All these costs need to be considered and, to the extent 
possible, minimised, through adequate policies both in countries of origin and in host countries."

Finally, future studies in the economics and social perspectives of immigrants furnish a great deal of opportunities. In-depth studies of career choice among the immigrants may provide insights for better policy in the host country (Diaz-Serrano, 2010). In the same vein, economics of labor law with regard to competitiveness proves the needs for more studies especially for developing worlds (Sykes, 2011).

\section{Acknowledgement}

We are very grateful to Research Management Institute (RMI) of Universiti Teknologi MARA for the research grant that provides sufficient fund for research completion.

\section{References}

Abe, A. (2005). Citizenship, colonial post and immigration policy: A comparative study between Japan and United Kingdom. Paper Present at the Annual Meeting of the International Studies of Association, Hilton Hawaiian Village, Honolulu, Hawaii.

Ahmad, N., Hussain, Z., Sial Hussain, M. H., \& Akram, W. (2008). Macroeconomic determinants of international migration from Pakistan. Pakistan Economic and Social Review, 46(2), 85-99.

Alba, R., \& Nee, V. (2003). Remaking the American Mainstream. Assimilation and Contemporary Immigration. Cambridge, Mass.: Harvard University Press.

Alonso, J. E. (2011). International Migration and Development: A review in light of the crisis. CDP Background Paper No. 11(E). UNDP.

Aydemir, A. (2007). The impact of labor markets in Canada, Mexico, and the United States. Up-date on Family Labour Studies, 89, 1703-2415.

Borjas, G. J. (2001). Does immigration grease the wheels of the labor market? Brookings Papers on Economics Activity, 1.

Borjas, G. J. (2004). The Labor Market Impact of High-Skill Immigration. Harvard University Press.

Borjas, G. J. (2006). The impact of immigration on the labor market. Conference Paper on Labor and Capital Flows in Europe. International Monetary Fund, Vienna Institute, and the National Bank of Poland.

Borjas, G. J., Grogger, J., \& Hanson, G. H. (2008). Imperfect Substitution between Immigrants and Natives: A Reappraisal. Harvard University Publication. http://dx.doi.org/10.3386/w13887

Caselli, F., \& Feyrer, J. (2007). The marginal product of capital. Quarterly Journal of Economics, 122(2), 535-568.

Castles, S. (2000). Migration as a factor in social transformation in East Asia, Paper Conference on Migration and Development. Princeton University.

Chantavanich, S. (2007). Factors affecting Thailand immigration policies during 1992-2004. Institute of Social Study. The Netherland.

Cohen, R. (1987). The New Helots: Migrants in the International Division of Labour. Aldershot: Avebury.

Collinson, S. (1993). Beyond Borders: West European Migrant Policy Towards the 21st Century. London: RIIP. Wyndham Place Trust.

De Palo, D., Faini, R., \& Venturini, A. (2007). The social assimilation of immigrants. Social Protection. The world bank. Discussion Paper No. 0701.

Diaz-Serrano, L. (2010). Do legal immigrants and natives compete in the labour market? Evidence from Catalonia. Discussion Paper No. 4693. Universitat Rovira Virgili and IZA.

Facchini, G., \& Mayda, A. M. (2009). The Political economy of immigration Policy. The United Nation development Programme: Human Development Report. Research Paper No. 2009/3.

Freidberg, R. M. (2001). The impact of mass migration on the Israeli labor market. Quarterly Journal of Economics, 116, 1373-1408. http://dx.doi.org/10.1162/003355301753265606

Ginannone, D., \& Lenza, M. (2009). The Feldstein-Horioka Fact. NBER Working Paper 15519, National Bureau of Economic Research.

Hair, J. F., Black, W. C., Babin, B. J., Anderson, R. E. \& Tatham, R. L. (2006). Multivariate data analysis (6th ed.). NJ: Pearson-Prentice Hall.

Kanapathy, V. (2006). International migration and labour market developments in Asia: Fine tuning the policy and institutional framework for managing cross-Border labour flows. Paper for the Workshop on 
International Migration and Labour Market in Asia. Japan Institute of Labour, Tokyo, Japan.

Kanapathy, V. (2007). Migrant workers in Malaysia: An overview. Paper prepared for the Workshop on East Asia Cooperation Framework for Migrant Labour. Kuala Lumpur.

Kassim, A. (1987). The unwelcome guests: Indonesian immigrants and Malaysian public responses. Southeast Asian Studies, 25(2).

Kassim, A. (1991). Recruitment and unemployment of Indonesian workers: Problem and major policy issues. The ILO Inter-Country Workshop on Migrant Labour in Plantation Industry. Kuala Lumpur.

Kassim, A. (2005). Cross-border movement of foreign workers in Malaysia: A comparative analysis. An Article in Master Builders (3rd Quarter).

Kaufman, B. E. (2011). Economic analysis of labor markets and labor law: An institutional/industrial relations perspective. W. J. Usery Workplace Research Group Paper Series. Georgia State University.

Krally, E. P. (1995). U.S. Immigration and the environment: Scientific research and analytic issue. The US Commission and Immigration reform.

Lewis, W. A. (1969). Aspects of Tropical Trade. Wicksell Conference, Stockholm, Almqvist and Wicksell.

Lewis, W. A. (1983). Crecimiento y fluctuaciones, 1870-1913. Mexico, Fondo de Cultura Económica.

Lindert, P. H., \& Williamson, J. G. (2001). Does globalization make the world more unequal? NBER Working Paper 8228. National Bureau of Economic Research.

Mosisa, A. T. (2002). The role of foreign born workers in the US economy. Monthly Labor Review, 3-14.

MYREN. (2006). Malaysia-Europe community strategy paper for the period of 2007-2013. Malaysian Research $\begin{array}{lllll}\text { Network. } & \text { Retrieved } & \text { November } & 20, & \text { from }\end{array}$ http://www.ec.europa.eu.external_relations/malaysia/csp/0713en.pdf

New Straits Times. (2011). Outbreak of leptospirosis, Myanmar illegal immigrant first victim, 26 more cases reported. Retrieved November 20, 2013, from http://en.wikipedia.org/wiki/Push_pull_factors

Nordin, M. (2009). Nasib penduduk minoriti Islam. Mingguan Malaysia.

Nye, J. S. (2009). The worse of all possible worlds. The New Straits Time.

Orreenius, P. M., \& Zavodny, M. (2006). Does immigrant affect wages? A look at occupational-level evidence. Research Department Working Paper 0302. Federal Reserve Bank of Dallas.

Osili, U. O., \& Du, D. (2005). Assimilation and Charitable Giving. Retrieved November 20, 2013, from http:/www.philanthropy.iupui.edu/Research/WorkingPapers/Immigrants\%20and\%20Charitable\%20Giving $18 \% 20(2)$ pdf

Ravenstein, E. G. (1885). The laws of migration. Journal of the Statistical Society, 46, 167-235.

Saadation, O., Mohd Tahir, O., \& Dola, K. (2010). Identifying challenges in implementing sustainable practices in a developing nation. Journal of Sustainable Development, 3(2), 107-116.

Schoeni, R. F., Stafford, F., McGonagle, K. A. \& Andreski, P. (2013). The nonresponse challenge to surveys and statistics. The Annals of the American Academy of Political and Social Science, 60, 645.

Selamat, A. (2009). Old issue and timing bomb. Mingguan Malaysia.

Sidiq, K. (2005). When states prefers non-citizens over citizens: Conflict over illegal immigration into Malaysia. International Study Quarterly, 49, 101-122. http://dx.doi.org/10.1111/j.0020-8833.2005.00336.x

Somerville, W. (2009). Immigrant and the labour market: Theory, evidence and policy. The Equality and Human Rights Commission.

Suparmaniam, S., \& David, A. (2009). No inside job. The New Straits Times.

Sykes, A. O. (2001). The welfare economics of immigration law: A theoretical survey with an analysis of U.S. policy. John M. Olin Law \& Economics Working Paper No. 10 (2D Series). University of Chicago.

Van Amersfoort, H., \& Van Niekerk, M. (2006). Immigration as a colonial inheritance: Post-colonial immigrants in the Netherlands, 1945-2002. Journal of Ethnic and Migration Study, 32, 323-346. http://dx.doi.org/10.1080/13691830600555210

Walton, M. (2009). Internal immigration in Cambodia-A case study of push-pull factors of immigration into Phnom Pehn. School of Natural and Built Environment, University of South Australia. North Terrace, Adelaide. 


\section{Appendix A}

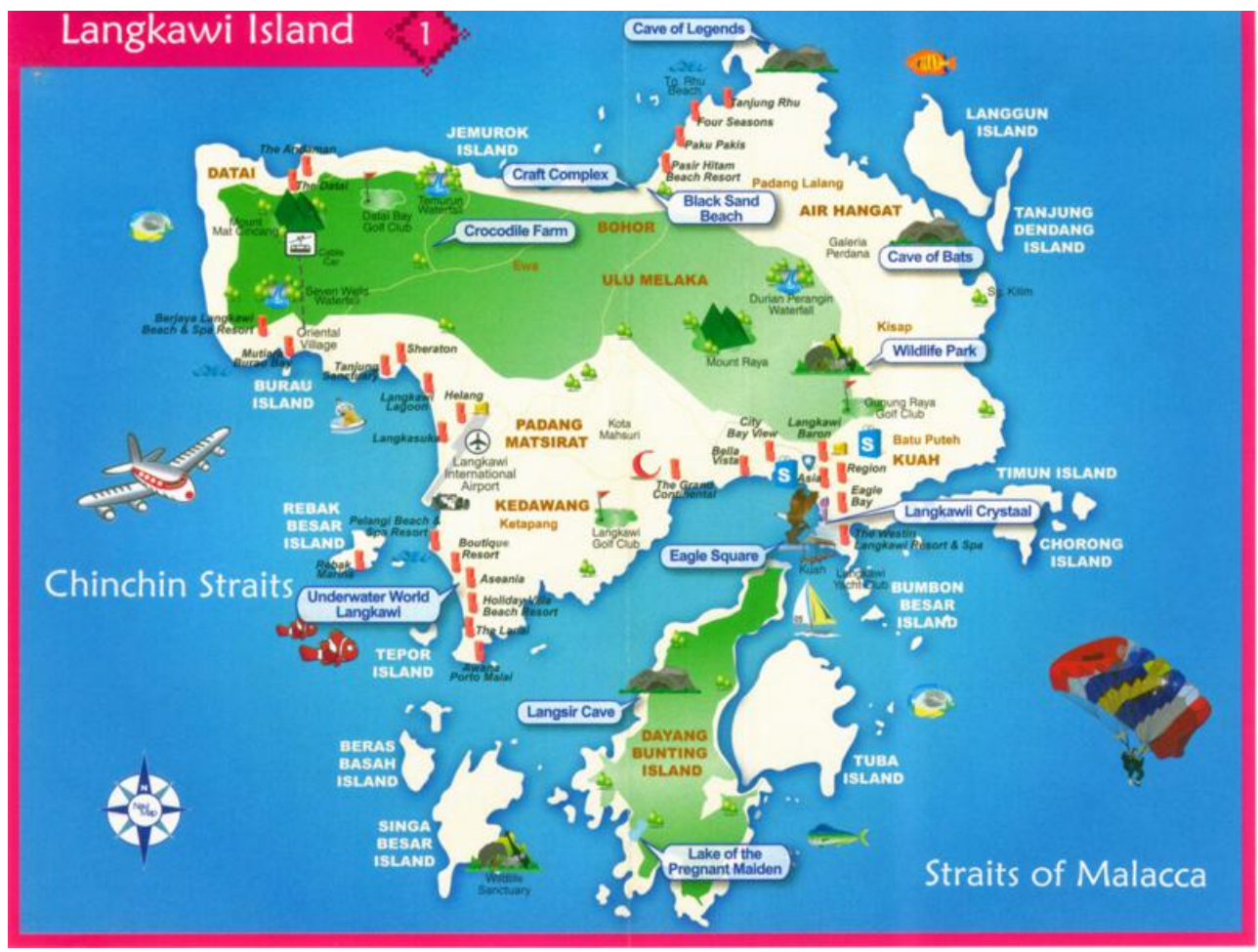

Figure 2. Map of Langkawi, Malaysia

\section{Appendix B}

Table 1. Items used in the questionnaire

\begin{tabular}{lll}
\hline Variable & Item & Scale* \\
\hline & 1. Employers prefer to hire MMMIs than local workers & $1-5$ \\
& 2. MMMIs willing to work with lower wage & $1-5$ \\
Wage competitiveness & 3. MMMIs are hardworking and diligent & $1-5$ \\
& 4. MMMis are protected under firms' HR policy & $1-5$ \\
& 5. MMMIs possess valid work permits & $1-5$ \\
& 1. MMMIs seem to reside in Langkawi permanently & $1-5$ \\
Career distraction & 2. MMMIs involve in petty crime here (e.g. stealing) & $1-5$ \\
& 3. MMMIs have immunity from legal enforcement & $1-5$ \\
& 4. MMMIs should not be granted with citizenship status & $1-5$ \\
Environment nuisance & 1. MMMIs were not friendly with local community & $1-5$ \\
& 2. MMMIs settlement area was in very poor condition & $1-5$ \\
Perception & 3. MMMIs presence give bad impression to tourism industry & $1-5$ \\
socioeconomic impact & 4. MMMIs trade transactions were within their own community & $1-5$ \\
\hline
\end{tabular}

* Scale: 1 - Strongly disagree, 2 - Disagree, 3 - Neither agree nor disagree, 4 - Agree, 5 - Strongly agree. 


\section{Appendix C}

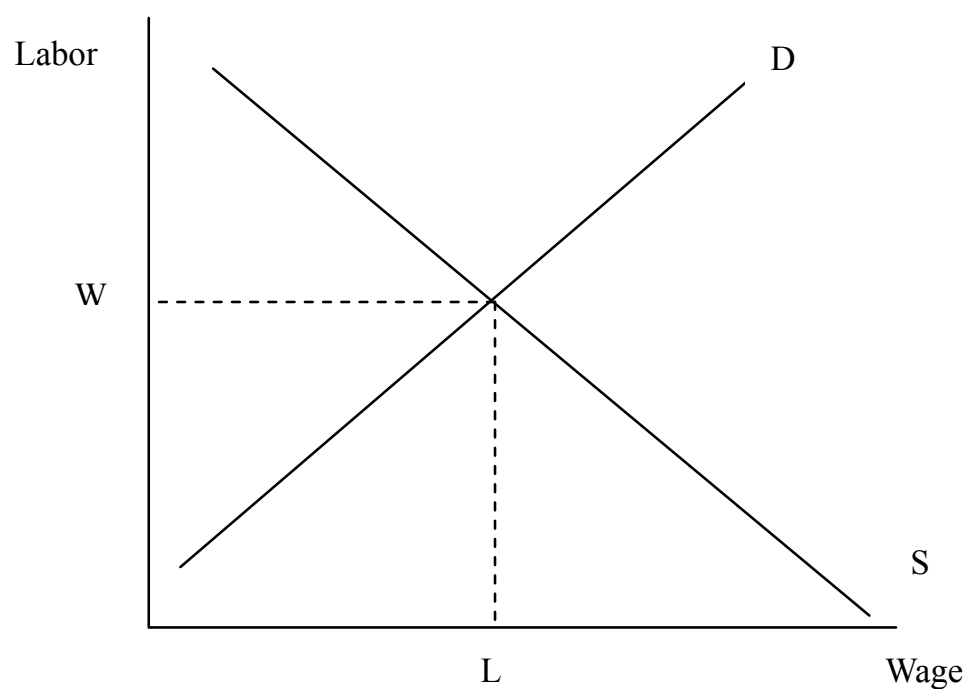

Figure 3. Competitive labor market

Figure 3 illustrates the competitive demand/supply (DS) labor market model; it is an application to the labor market of the generic competitive market model that is a ubiquitous feature of scholarly expositions of modern L\&E (e.g., Mercuro \& Medema, 1997; Posner, 2007; Cooter \& Ulen, 2010). The labor demand curve D and supply curve $\mathrm{S}$ determine an equilibrium wage $\mathrm{W}$ and employment level $\mathrm{L}$. This conclusion by itself is not of great significance for analysis of labor law; what matters are the implications for social welfare.

One desirable social welfare property, mentioned in the Solow quote, is that competitive markets yield market-clearing prices and quantities. This means that competition causes wage rates to rise or fall until equilibrium is established where demand and supply are evenly balanced and neither a shortage nor excess of labor prevails. The beneficial aspect of market clearing is most apparent at the aggregate level; that is, the implication is that a competitive market economy automatically and without government guidance ("as if by an invisible hand") tends to correct demand/supply imbalances and yield an equilibrium where the number of jobs available matches the number of people wanting to work (a definition of full employment).

A second desirable property, also alluded to in the Solow quotation, is that a competitive market economy leads to an efficient use of resources. Full employment of labor is clearly one dimension of efficiency (unemployment is a waste of labor resources). Another dimension is that competition and competitive wage rates sort and assign the nation's heterogeneous labor resources to their most productive use (e.g., the people with a comparative advantage at plumbing end up being plumbers). Yet a third dimension is that competition prevents employers from exploiting (underpaying) workers and provides employers with strong incentives to treat workers fairly (e.g., ill-treatment leads to a high turnover rate, a reputation as a bad employer, and less loyal and committed employees). A final dimension of efficiency, known as Pareto optimality, is that the nation's resources are allocated and utilized with no slack or waste; that is, the production of goods and services (or "wealth") is at the economy's maximum limit and one person therefore can get more goods and services only if another gets less.

The DS model and the conditions and implications that come from it are, of course, highly idealized; further, as described in more detail below economists in the NE/NIE tradition have persuasively argued that many seeming labor market problems (e.g., unemployment, gender wage differentials) are actually efficient or competitive-like responses to underlying productivity, cost, and taste differentials. Not all economists, however, accept either the standard competitive model or the extended NE/NIE efficient contract version as useful interpretations of labor markets; others use them only as rough and ready benchmarks to get the analysis started.

Hence a wide spectrum of opinion exists among economists regarding two related questions. The first is how well the competitive model and its various extensions and generalizations serve as a useful device for understanding and explaining labor markets and employment relationships; the second is to what degree the outcomes of a competitive labor market, even if attained, are beneficial for human welfare and therefore a desired object of public policy (Adopted from: Kaufman, 2011). 


\section{Copyrights}

Copyright for this article is retained by the author(s), with first publication rights granted to the journal.

This is an open-access article distributed under the terms and conditions of the Creative Commons Attribution license (http://creativecommons.org/licenses/by/3.0/). 